\title{
Schizophrenia and Its Genetic Basis: A Review Study
}

\author{
Somayeh Maleki ${ }^{*}$, Mohammad Ali Taheri ${ }^{2}$
}

\section{ABSTRACT}

Background: Schizophrenia is a devastating mental illness that interferes with the patient's social and occupational functioning and impairs the patient's life. Methods: The research method is a Review Study based on library, documentary and field studies. Results: Studies indicate the bio-genetic basis in the etiology of schizophrenia disorder; however, the mystery of the formation of this disease is still somewhat unknown. Parents' age is considered as an effective index on incidence of children to psychotic disorders. Studies show that parents' higher age is associated with having children with schizophrenia and mostly parents, who have children with schizophrenia under the legal age, do not live with their child. Conclusion: This study was a review study, the results of which can be useful in planning preventive interventions.

Keywords: Schizophrenia, Genetic

Schizophrenia is a devastating mental illness that interferes with the patient's social and occupational functioning and impairs the patient's life (Bachmann et al., 2005). Psychosis is a general term that is used to determine the most severe psychiatric disorders caused by disintegration of thought processes, emotional disorders, loss of spatial and temporal orientation, inability to evaluate the outer reality, not compromised response to usual requirements of life, existence of delusions and hallucinations in some cases, and in general, damaging the character by pathological process. This syndrome leads to vulnerability in individuals' social life (Bartels et al., 2003). Studies indicate the bio-genetic basis in the etiology of schizophrenia disorder (Shih et al., 2004). However, the mystery of the formation of this disease is still somewhat unknown (Lee et al., 2016). In treatment-resistant psychotic patients than psychotic patients' respondent to treatment, dopamine synthesis is lower (Demjaha et al., 2012). Lack of response to treatment can be in the form of side effects, neuroleptic syndrome, extra pyramidal syndrome, weight gain, lack of therapeutic cooperation and mortality in psychotic patients Naumovska et al., 2015). With respect to biological system, high density in dopaminergic receptors is associated with favorable therapeutic prognosis (Robert et al., 2009). However, due to individual differences,

\footnotetext{
${ }^{1}$ Graduate Degree in Psychology, Department of Psychology, Payame Noor University (PNU), Tehran, Iran

${ }^{2}$ Iranian Researcher on Alternative Medicine, Tehran, Iran

*Responding Author

Received: February 10, 2017; Revision Received: March 21, 2017; Accepted: March 29, 2017
}

(C) 2017 Maleki S, Taheri M; licensee IJIP. This is an Open Access Research distributed under the terms of the Creative Commons Attribution License (www.creativecommons.org/licenses/by/2.0), which permits unrestricted use, distribution, and reproduction in any Medium, provided the original work is properly cited. 


\section{Schizophrenia and Its Genetic Basis: A Review Study}

codification of a prevention and treatment program in the area of schizophrenia requires unique therapeutic approaches (Thibaut, 2014). In regard to existence of individual differences in psychotic patients, even smoking cigarette can cause difference in the conclusion of the treatment because of affecting on levels of blood plasma (Huang et al., 2016). These individual differences are often explained as a genetic diversity (Zhang et al., 2010). Even in the case of the same genotypes, also, some differences in the response and severity of psychotic symptoms can be seen (Ota et al., 2012). Recent studies show that environmental change can cause certain symptoms in psychotic patients that are famous as "isolation syndrome" and are associated with increasing anxiety, hyperactivity and learning and memory impairment (Oliveras et al., 2016). Some parts of reasons explaining schizophrenia disorder should be explained in case of genetic changes. Hereditary factors that are transferred from one generation to another are called gens. Gens are located in all parts of a giant molecule called Ribonucleic acid Dzaksy of DNA. DNA changes into the form of nucleoprotein accompanied proteins that appear in form of chromosome in special staining in the cell nucleus. A gen includes some information that protein is built by its help. DNA molecule is stable and has the power of replication. Change of a part of molecule's structure is called mutation. Mutation, in fact, is associated with changing the information existing in DNA molecule that as a result, a defective protein appears or building protein is totally cut. However, it should be considered that the final result of mutation is creating new characteristics in individuals of a spice. A gen can change into various shapes because of multiple mutations that are called El morph or in a row set of genes. Each gene occupies a special place on a chromosome that is called locus. In this way, all in row genes occupy specific place of the primary gene on the same chromosome. The term locus sometimes is applied instead of the term gene. In short, in the early time of appearance of genetics, gene was thought as an independent factor that was located on a string throughout chromosome like beads. Parents' age is considered as an effective index on incidence of children to psychotic disorders. Studies show that parents' higher age is associated with having children with schizophrenia and mostly parents who have children with schizophrenia under the legal age, do not live with their child (Schrank et al., 2016). Increasing parents' age is associated with increase in risk of incidence of the child to autism spectrum disorders (Byars \& Boomsma, 2016). Scientific evidence suggests that prenatal factors in psychotic patients, compared to non-psychotic individuals, are a predictor of mortality in this group of patients (Rautio et al., 2016). This study was a review study, the results of which can be useful in planning preventive interventions.

\section{Acknowledgments}

The author appreciates all those who participated in the study and helped to facilitate the research process.

\section{Conflict of Interests:}

The author declared no conflict of interests. 


\section{REFERENCES}

Bachmann RF, Schloesser RJ, Gould TD, Manji HK. Mood stabilizers target cellular plasticity and resilience cascades: implications for the development of novel therapeutics. Mol Neurobiol. 2005;32:173-202. doi: 10.1385/MN:32:2:173. [PubMed]

Bartels SJ, Clark RE, Peacock WJ, Dums AR, Pratt SI. Medicare and medicaid costs for schizophrenia patients by age cohort compared with costs for depression, dementia, and medically ill patients. Am J Geriatr Psychiatry. 2003;11:648-657. doi: 10.1097/00019442-200311000-00009 .[PubMed]

Byars, S. G., \& Boomsma, J. J. (2016). Opposite differential risks for autism and schizophrenia based on maternal age, paternal age, and parental age differences. Evolution, Medicine, and Public Health, 2016(1), 286-298. [PubMed]

Demjaha A, Murray RM, McGuire PK, Kapur S \& Howes OD: Dopamine Synthesis Capacity in Patients With Treatment-resistant Schizophrenia. Am J Psychiatry 2012; 169:1203-1210. [PubMed]

Huang, H. C., Lua, A. C., Wu, L. S., Wu, B. J., Lee, S. M., \& Liu, C. Z. (2016). Cigarette smoking has a differential effect on the plasma level of clozapine in Taiwanese schizophrenic patients associated with the CYP1A2 gene-163A/C single nucleotide polymorphism. Psychiatric genetics. [PubMed]

Lee, B. D., Park, J. M., Lee, Y. M., Moon, E., Jeong, H. J., Chung, Y. I., \& Yi, Y. M. (2016). Heritability and Familiality of Temperament and Character Dimensions in Korean Families with Schizophrenic Linkage Disequilibrium. Clinical Psychopharmacology and Neuroscience, 14(2), 203. [PubMed]

Naumovska, Z., Nesterovska, A. K., Filipce, A., Sterjev, Z., Brezovska, K., Dimovski, A., \& Suturkova, L. (2015). Pharmacogenetics and Antipsychotic Treatment Response/Фармакогенетски Тестирања И Одговор Кон Третман Со Антипсихотоци. prilozi, 36(1), 53-67. [PubMed]

Oliveras, I., Sanchez-Gonzalez, A., Piludu, M. A., Gerboles, C., Río-Álamos, C., Tobena, A., \& Fernández-Teruel, A. (2016). Divergent effects of isolation rearing on prepulse inhibition, activity, anxiety and hippocampal-dependent memory in Roman high-and low-avoidance rats: A putative model of schizophrenia-relevant features. Behavioural Brain Research, 314, 6-15. [PubMed]

Ota VK, Spindola LN, Gadelha A, dos Santos Filho AF, Santoro ML, Christofolini DM et al.: Drd1 Rs4532 Polymorphism: a Potential Pharmacogenomic Marker for Treatment Response to Antipsychotic Drugs. Schizophr Res 2012; 142:206-208. [PubMed]

Rautio, N., Miettunen, J., Jääskeläinen, E., Nordström, T., Isohanni, M., \& Seppälä, J. (2016). Do adverse perinatal events predict mortality in schizophrenia during midlife?. Schizophrenia Research. [PubMed]

Roberts RC, Roche JK, Conley RR \& Lahti AC: Dopaminergic Synapses in the Caudate of Subjects With Schizophrenia: Relationship to Treatment Response. Synapse 2009; 63:520-530. [PubMed] 


\section{Schizophrenia and Its Genetic Basis: A Review Study}

Schrank, B., Rumpold, T., Gmeiner, A., Priebe, S., \& Aigner, M. (2016). Parenthood among patients with psychotic disorders: gender differences in a non-selective clinical sample. Psychiatry Research, 246, 474-479.

Shih RA, Belmonte PL, Zandi PP. A review of the evidence from family, twin and adoption studies for a genetic contribution to adult psychiatric disorders. Int Rev Psychiatry. 2004;16:260-283. doi: 10.1080/09540260400014401 .[PubMed]

Thibaut F: Acute Treatment of Schizophrenia: Introduction to the Word Federation of Societies of Biological Psychiatry Guidelines. Psychiatr Danub 2014; 26:2-11. [PubMed]

Zhang JP, Lencz T \& Malhotra AK: D2 Receptor Genetic Variation and Clinical Response to Antipsychotic Drug Treatment: a Meta-analysis. Am J Psychiatry 2010; 167:763-772. [PubMed]

How to cite this article: Maleki S, Taheri M (2017), Schizophrenia and Its Genetic Basis: A Review Study, International Journal of Indian Psychology, Volume 4, Issue 2, No. 95, ISSN:2348-5396 (e), ISSN:2349-3429 (p), DIP:18.01.161/20170402, ISBN:978-1-365-84231-3 